\title{
The effect of the presence of e-commerce on consumer purchasing decisions
}

\author{
Ida Zuniartia ${ }^{*}$, Idah Yuniasih ${ }^{a}$, I Ketut Martana ${ }^{a}$, Eka Dyah Setyaningsih ${ }^{a}$, Isnurrini Hidayat \\ Susilowati $^{\mathrm{a}}$, Eigis Yani Pramularso ${ }^{\mathrm{a}}$ and Dewi Astuti ${ }^{\mathrm{a}}$
}

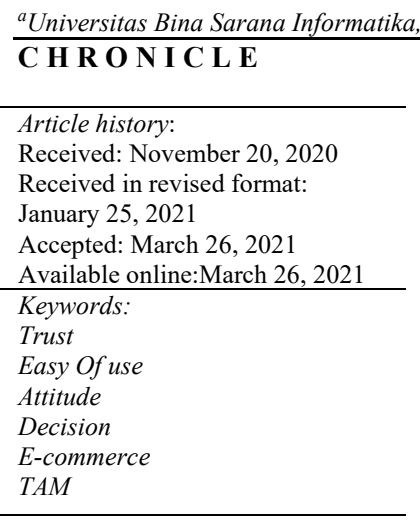
\begin{abstract}
A B S T R A C T
In this study, researchers examined how consumer decisions on purchases in e-commerce are particularly influenced by trust, attitudes and the ease of new shopping places. The data collection research was conducted using a questionnaire with 130 consumer respondents who had bought at ecommerce which would later be processed by Amos' Structural Equation Modeling (SEM). The study used four variables, thirteen dimensions and twenty-six indicators. The results showed that trust, convenience and attitudes influenced consumer decisions in buying e-commerce. The results also showed that trust had the greatest and most significant influence on consumer decisions to buy in e-commerce. So, it can be said that consumers buy because it is based on a sense of already trusting an e-commerce to make e-commerce crowded and buyers need to pay attention to improving their taste.
\end{abstract}

\section{Introduction}

In the current development era, consumer decisions can change due to new things (Suleman, 2018), because purchasing decisions are influenced by many things, one of which is the service of a place (Suleman, 2014), here it is necessary to understand that consumers want to get more things. good. Both in terms of the benefits they get shopping such as those offered in ecommerce (Suleman et al., 2019), there are many positive values that consumers can get when they shop at this new place. Where new and old competition occurs (Suleman et al., 2019). The basis of a purchase decision is trust (Suleman, Ali, et al., 2019). Consumers need to feel safe when shopping in e-commerce, of course this feeling is expected to be higher because consumers need to think about how their money is not lost (Suleman et al., 2019). Consumers need trust in a new place when they decide to make transactions (Suleman et al., 2020). Another factor that affects is the ease of shopping, it cannot be denied that consumers will shop where they feel the easiest (Suleman, Ali, et al., 2020b). Where, of course, certain generations of consumers will easily transact in e-commerce because it is done in an easy way for them where other consumers also consider offline shopping easier (Suleman, Ali, et al., 2020e; Rusiyati et al., 2021). So this cannot be measured with certainty but can be compared with the efforts of how we see e-commerce now that e-commerce makes shopping easier by using technology that is easy to use for ordinary people. The two factors above will also influence consumer decisions more if the attitude is added to be a big influence in the decision. Consumers certainly have their own personal attitudes before deciding (Suleman, Ali et al., 2020d). Where a positive attitude is an important basis because consumer perceptions of where to shop can form the basis of decisions. Although this attitude is relative to each consumer. Consumers who feel that they have made transactions in e-commerce and get goods as expected must have a positive attitude (Suleman et al., 2020). This attitude exists in consumers even though it is a big determinant, but it all depends on each one based on experience, environment, lifestyle and education (Suleman, Ali, et al., 2020c). This attitude has been widely researched and is the material for decision making research (Kotler et al., 2019). In addition, at the end the purchase decision is the most important thing that is the end of the 
consumer process that they have gone through from a series of purchasing processes (Kotler \& Amstrong, 2016). After various stimuli have been carried out, consumers will choose to shop in e-commerce according to their final choice (Suleman, Ali, et al., 2020a). So that this research will answer how consumer decisions actually occur.

\section{Theoretical framework and hypotheses development}

The purpose of this research is to describe the direct relationship between easy-of-use trust and attitudes toward consumer decisions. The following is an explanation used in this study to build the following hypothesis.

\subsection{Trust}

Trust is important and is a proven factor influencing the decision to shop based on several previous studies which state this in the results of their research, among others (Hsu et al., 2014; Al-Debei et al., 2015; Zeba \& Ganguli, 2016; Marriott \& Williams, 2018; Suleman et al., 2019). For this reason, the role of trust makes e-commerce a place to shop or not so that this can be the basis for determining and hypothesizing. Therefore, the researchers made the first hypothesis in this study as follows:

\section{$H_{1}$ : Trust has a significant effect on the purchasing decision.}

\subsection{Easy Of Use}

Every time you make a purchase, of course what you will choose is an e-commerce, which in the process is easy in the sense that new consumers can process transactions from ordering goods to payment processing and the ease of monitoring the transaction process, therefore the easier it is to understand and learn, it will make consumers choose to buy in an e-commerce and there are also many studies that state that this convenience is an influence on decisions, including research results, and (Alwafi \& Magnadi, 2016; Wahyuningtyas \& Widiastuti, 2017; Zolait et al., 2018; Shabrina \& Zaki, 2019; Cho \& Son, 2019). Sourced from the basis of this research, this convenience can be made a hypothesis in this study so that the researcher makes the second hypothesis in this study as follows:

\section{$\mathrm{H}_{2}$ : Easy of Use has a significant effect on the purchasing decision.}

\subsection{Attitude}

Consumers in themselves have attitudes based on previous beliefs and experiences in e-commerce, therefore an e-commerce that is their choice must have a positive value in consumers. The effect of attitudes on this decision has been widely researched and the results show that attitudes have an effect on consumer decisions in these studies, among others, (Tingchi Liu et al., 2012; Adnan, 2014; Wu \& Ke, 2015; Lee, 2016; Indarsin \& Ali, 2017; Suleman et al., 2020a). Therefore, the researcher made the third hypothesis in this study as follows:

$H_{3}$ : Attitude has a significant effect on the purchasing decision.

From the explanation of the hypothesis above, an image of the framework of thought in this study can be made as follows can be seen in Fig. 1 below:

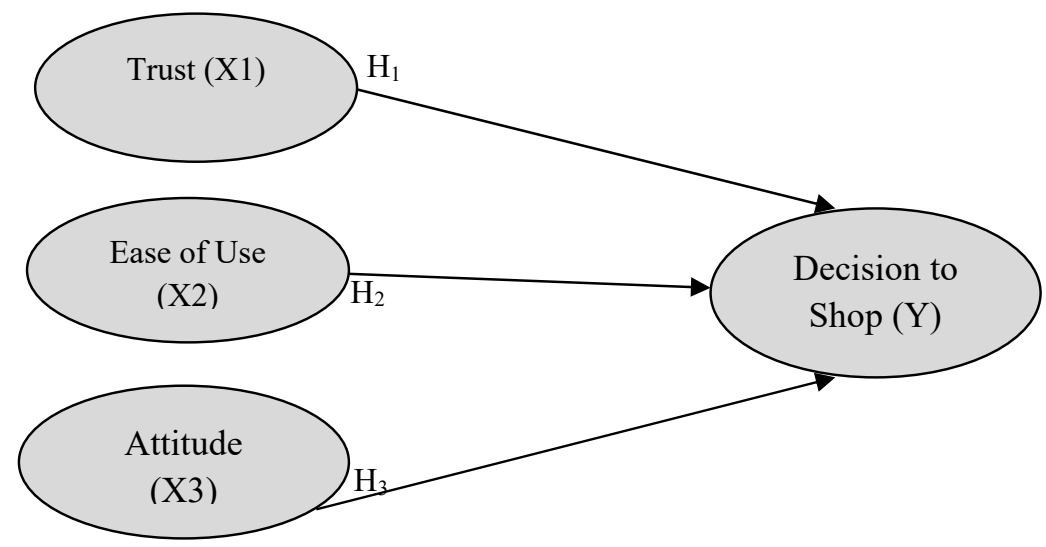

Fig. 1. Research Framework 


\section{Research methods}

\subsection{Population and Sample}

The population in this study is large and the number is not known with certainty. Therefore, the determination of the sample using a $5 \times$ calculation of the number of indicators as many as 130 respondents (Ferdinand, 2018). The sampling technique used in this study was quota sampling where the sample was. In this study using 4 variables, 13 dimensions and 26 indicators. Where each indicator becomes a statement that is asked of the respondent who is given 26 questions to be answered and the results will be tabulated. All questions used in this research have previously been tested so that the instruments are valid and reliable. where the results of the respondents' answers are then tabulated and processed using SEM AMOS 23.

\subsection{Data analysis and results measurement items}

This study uses three dimensions with six indicators for trust variables which have been adapted from research (Indarsin \& Ali, 2017) which has been adjusted. As for the ease of use variable, it uses three dimensions with six indicators taken from research (Suleman, Zuniarti, \& Sabil, 2019). Furthermore, consumer attitude variables use three dimensions and six indicators adapted from research (Suleman, Ali, et al., 2020a) and finally for purchasing decision variables using four dimensions with eight indicators obtained from adjusted theory (Philip \& Keller, 2016). All 26 indicators were measured using a scale of 1 "Strongly Disagree" to 5 "Strongly Agree".

\subsection{SEM AMOS Analysis}

Goodness Of Fit (GOF) Analysis

The results of the first AMOS SEM test which aims to determine whether the overall compatibility model will be compared between the data entered and the standards owned by Amos. And the output of SEM AMOS results the data output on the overall compatibility test can be seen in Table 1 below:

\section{Table 1}

The results of the goodness of fit (GOF)

\begin{tabular}{lccccc}
\hline Measure & \multicolumn{2}{c}{ Measurement } & & \multicolumn{2}{c}{$\begin{array}{c}\text { Measurement } \\
\text { Result }\end{array}$} \\
\cline { 2 - 3 } Absolute fit Model & Good Fit & Marginal Fit & & & Good Fit \\
Goodness of fit Index (GFI) & & & & & \\
Root Mean Square Error (RMSEA) & $\geq 0.90$ & $0.80-<0.90$ & 0.90 & Good Fit \\
Incremental Fit Model & $<0.08$ & & 0.041 & \\
Comparative Fit Index (CFI) & & & & \\
Normal Fit Index (NFI) & $\geq 0.90$ & $0.80-<0.90$ & 0.93 & Good Fit \\
Incremental Fit Index ( IFI) & $\geq 0.90$ & $0.80-<0.90$ & 0.81 & Marginal Fit \\
$\begin{array}{l}\text { Relative fit Index (RFI) } \\
\text { Parsimonious Fit Model }\end{array}$ & $\geq 0.90$ & $0.80-<0.90$ & 0.92 & Good Fit \\
Parsimonious normed fit index (PNFI) & $\geq 0.90$ & $0.80-<0.90$ & 0.83 & Marginal Fit \\
\hline
\end{tabular}

Results of Overall Model Processing (GOF) If seen in Table 1 which is the SEM output from AMOS, the absolute fit size data model is found which aims to determine the level of prediction of all models (structural and measurement models) to data suitability consisting of RMSEA $0.041<0,08$ (model fit) and a GFI value of 0.90 . It can be concluded that all the models tested are close to the absolute fit model testing criteria at a fairly good level of testing criteria. And for other model fit criteria, the Incremental Fit Model consists of several conformity test instruments, namely the value of CFI $=0.93 ; \mathrm{NFI}=0.81 ; \mathrm{IFI}=$ 0.92 and RFI $=0.83$, the results state that the structural equation model is said to be good because it is at a fairly good level of testing criteria and has met the requirements of the Incremental Fit Model. On the fit size, the stingy fit model can be seen in the PNFI results $=0.86$; From these outputs it can be concluded that the model is said to be at the level of testing criteria is quite good and meets the requirements of the parsimonious fit model.

\subsection{Measurement Model}

The second output result in SEM AMOS shows the following data results. According to (Ferdinand, 2018) the composite reliability of a measurement model is said to be good reliability to measure each latent variable if the construct reliability value $(\mathrm{CR})$ is $\geq 0.7$ or more than the value of extracted variance (VE) is greater than 0.05 , states that in exploration reliability research between 0.5 - 0.6 can be accepted and then at SEM AMOS a one-way test is carried out with a 95\% confidence level, the commonly used critical value $(\mathrm{CR})>1.96$ which means the assumption of normality is rejected at significance level $(\mathrm{P})$ $<0.05(5 \%)$. 
Table 2

Construct reliability and variance extracted

\begin{tabular}{|c|c|c|c|c|c|}
\hline Constructs & $\begin{array}{l}\text { Item } \\
\text { Code }\end{array}$ & $\begin{array}{c}\text { Factor } \\
\text { Loadings }\end{array}$ & (Error) & $\mathrm{CR}$ & VE \\
\hline \multirow[t]{6}{*}{ Trust } & TS1 & 0.82 & 0.63 & \multirow[t]{6}{*}{0.87} & \multirow[t]{6}{*}{0.50} \\
\hline & TS2 & 0.70 & 0.52 & & \\
\hline & TS3 & 0.76 & 0.58 & & \\
\hline & TS4 & 0.72 & 0.41 & & \\
\hline & TS5 & 0.83 & 0.67 & & \\
\hline & TS6 & 0.86 & 0.42 & & \\
\hline \multirow[t]{6}{*}{ Ease Of Use } & EU7 & 0.72 & 0.51 & \multirow[t]{6}{*}{0.90} & \multirow[t]{6}{*}{0.50} \\
\hline & EU8 & 0.80 & 0.59 & & \\
\hline & EU9 & 0.81 & 0.61 & & \\
\hline & EU10 & 0.73 & 0.63 & & \\
\hline & EU11 & 0.77 & 0.61 & & \\
\hline & EU12 & 0.83 & 0.59 & & \\
\hline \multirow{6}{*}{ Attitude } & ATD13 & 0.83 & 0.60 & \multirow[t]{6}{*}{0.85} & \multirow[t]{6}{*}{0.50} \\
\hline & ATD14 & 0.78 & 0.57 & & \\
\hline & ATD15 & 0.76 & 0.62 & & \\
\hline & ATD16 & 0.74 & 0.62 & & \\
\hline & ATD17 & 0.74 & 0.68 & & \\
\hline & ATD18 & 0.75 & 0.61 & & \\
\hline \multirow{8}{*}{ Decision } & DCS19 & 0.79 & 0.56 & \multirow[t]{8}{*}{0.86} & \multirow[t]{8}{*}{0.60} \\
\hline & DCS20 & 0.81 & 0.59 & & \\
\hline & DCS21 & 0.80 & 0.60 & & \\
\hline & DSC22 & 0.79 & 0.70 & & \\
\hline & DCS23 & 0.80 & 0.60 & & \\
\hline & DSC24 & 0.79 & 0.64 & & \\
\hline & DSC 25 & 0.81 & 0.61 & & \\
\hline & DSC26 & 0.78 & 0.57 & & \\
\hline
\end{tabular}

From Table 2 data it is found that all 26 indicators are valid and reliable because (CR) is $\geq 0.7$ or more than the value of extracted variance (VE) is greater than 0.05

\subsection{Match analysis of structural models or hypothesis testing}

The next step is to look at the structural model or hypothesis test in this case it can be seen about how the conclusions of the hypothesis in this study can be seen in Table 3 below:

Table 3

Hypotheses test results

\begin{tabular}{cllccc}
\hline No & & \multicolumn{1}{c}{ Hypotheses } & SLF1) & t-value & Conclusion \\
\hline 1 & H1 & Trust $\rightarrow$ Decision & 0,68 & 8.0 & Supported \\
2 & H2 & Easy Of Use $\rightarrow$ Decision & 0.28 & 2.2 & Supported \\
3 & H3 & Attitude $\rightarrow$ Decision & 0.56 & 5.2 & Supported \\
\hline
\end{tabular}

In the hypothesis test results in Table 3, which is the result of SEM AMOS output data processing which shows that the five are accepted, meaning that $(\mathrm{H} 1-\mathrm{H} 3)$ all show an effect and are significant. The basis for decision making is influential and significant based on the value of the $\mathrm{t}_{\text {-value }}>\mathrm{T}$-table 1.96 and $\alpha<0.05$, where the magnitude of the effect can be seen in the resulting SLF value which shows how much influence the independent variable has on the dependent. The test results show that trust (H1) has a positive and significant effect on decision with an output value of 8.0 greater than the table 1.96 and a standardized coefficient of 0.68 . Then (H2) ease of use towards decision, the t-value is 2.2 which is also greater than the $t-$ table (1.96) with a standard coefficient of 0.28 . Whereas for $(\mathrm{H} 3)$ attitude towards the decision found the values of 5.2 which are also greater than the table (1.96) with a coefficient of 0.56 .

\section{Discussions and conclusion}

After seeing the results of research that has been conducted by researchers, the researchers conclude. Where the basis for this conclusion is obtained from the results obtained, among others, it shows that trust has an effect and is significant on decisions, ease of use has an effect and is significant on decisions and finally that consumer attitudes have a significant and significant effect on consumer decisions. And the results found that the factor that has the greatest influence and significance on consumer decisions is consumer trust in e-commerce. The results of the first study found that trust has a significant effect on consumer decisions, this reinforces previous studies which have many of the same results. In determining the factors that need to be made positive, the main thing is consumer trust, therefore entrepreneurs or e-commerce owners must strive to increase consumer confidence in e-commerce, in this case the part that needs to be improved is the sense of transaction security in payments 
made. for it is at the heart of all the indecisiveness that the consumer thinks. when an e-commerce can convince a sense of trust for transactions, the consumer's decision to buy is not a difficult thing to materialize.

The results of the second study found in this study were that ease of use had a significant and significant effect on consumer decisions, this is also something that has naturally happened and has been widely discussed in previous studies. Because indeed the name ease of use will be a determining factor once again even though people already believe, but if it is difficult to make transactions or the process is confusing, consumers will still choose other e-commerce that is easier in the process of using it. E-commerce uses a new system which must be made easy and immediately understood by even new users.

The results of the third study indicate that attitudes have an effect and are significant on consumer decisions. These results also reinforce previous research which showed the same results. Here it is necessary to understand by e-commerce owners that indeed today's consumers have different characters, they have different backgrounds and are born in different generations which of course have an effect on negative and positive attitudes towards e-commerce, therefore for certain generations it is certain have a positive attitude supported by trust and ease of use of e-commerce, therefore efforts that can be done are to show a sense of help in every transaction process that consumers go through and this can change consumer attitudes towards e-commerce.

\section{Limitation}

In this study of course there are still many shortcomings and limitations, among others, the researchers' suggestions for future researchers, especially on the number of variables that affect consumer decisions where other variables can be added such as enjoyment and risks that affect decisions such as in research (Suleman et al., 2019)

\section{References}

Rusiyati, S., Suleman, D., Riftiasari, D., Suharyadi, D., Marwansyah, S., \& Sabil, S. (2021). How Enjoyment, Trust in Intention when choosing a shopping place. Dinasti International Journa of Management Science, 2(4), 551-560.

Adnan, H. (2014). An Analysis of the Factors Affecting Online Purchasing Behavior of Pakistani Consumers. International Journal of Marketing Studies, 6(5), 133-148. https://doi.org/10.5539/ijms.v6n5p133

Al-Debei, M. M., Akroush, M. N., \& Mohamed Ibrahiem Ashouri. (2015). Consumer attitudes towards online shopping: The effects of trust, perceived benefits, and perceived web quality. Internet Research, 25(5), 707-733.

Alwafi, F., \& Magnadi, R. H. (2016). Pengaruh Persepsi Keamanan, Kemudahan Bertransaksi, Kepercayaan Terhadap Toko Dan Pengalaman Berbelanja Terhadap Minat Beli Secara Online Pada Situs Jual Beli Tokopedia.Com. Journal of Management, 5(2), 1-15.

Cho, E., \& Son, J. (2019). The effect of social connectedness on consumer adoption of social commerce in apparel shopping. Fashion and Textiles, 6(1), Pp. 1-17. https://doi.org/10.1186/s40691-019-0171-7

Ferdinand, A. (2018). Metode penelitian manajemen. Universitas Diponegoro.

Hsu, M. H., Chuang, L. W., \& Hsu, C. S. (2014). Understanding online shopping intention: The roles of four types of trust and their antecedents. Internet Research, 24(3), 332-352. https://doi.org/10.1108/IntR-01-2013-0007

Indarsin, T., \& Ali, H. (2017). Attitude toward Using m-Commerce: The Analysis of Perceived Usefulness Perceived Ease of Use, and Perceived Trust: Case Study in Ikens Wholesale Trade, Jakarta - Indonesia. Saudi Journal of Business and Management Studies, 2,(11), 995-1007. https://doi.org/10.21276/sjbms.2017.2.11.7

Kotler, P., \& Amstrong, G. (2016). Prinsip-prinsip Pemasaran. Edisi13. Jilid 1. Erlangga.

Kotler, P., Kartajaya, H., \& Setiawan, I. (2019). Marketing 4.0: Moving From Traditional To Digital. In Gramedia. PT. Gramedia Pustaka Utama. https://doi.org/10.1142/9789813275478_0004

Lee, H. S. (2016). Examining neighborhood influences on leisure-time walking in older Korean adults using an extended theory of planned behavior. Landscape and Urban Planning, 148, 51-60. https://doi.org/10.1016/j.landurbplan.2015.12.011

Marriott, H. R., \& Williams, M. D. (2018). Exploring consumers perceived risk and trust for mobile shopping: A theoretical framework and empirical study. Journal of Retailing and Consumer Services, 42, 133-146. https://doi.org/10.1016/j.jretconser.2018.01.017

Philip, K., \& Keller, K. L. (2016). Marketing Management 16 edition. Pearson Prentice Hall.

Rusiyati, S., Suleman, D., Riftiasari, D., Suharyadi, D., Marwansyah, S., \& Sabil, S. (2021). How Enjoyment, Trust in Intention when choosing a shopping place. Dinasti International Journal of Management Science, 2(4), 551-560

Shabrina, R., \& Zaki, B. (2019). The Influence of Perceived Usefulness, Ease of Use, Attitude, Self-efficacy, and Subjective Norms Toward Intention to Use Online Shopping. International Business and Accounting Research Journal, 3(1), 1-14. https://doi.org/DOI: http://dx.doi.org/10.15294/ibarj.v3i1

Suleman, D. (2014). PENGARUH KUALITAS PELAYANAN TERHADAP KEPUASAN KONSUMEN PADA RESTAURANT MY BENTO. Perspektif, 12(2). https://doi.org/DOI: https://doi.org/10.31294/jp.v12i2.1143

Suleman, D. (2018). Faktor Penentu Keputusan Konsumen Indonesia MemilihTempat Belanja Disebuah E-Commerce (Theory of Planned Behavior). Jurnal JDM, I(02), 1-9. http://journal.mercubuana.ac.id/index.php/jdm/article/view/4120

Suleman, D., Ali, H., Nusraningrum, D., \& Ali, M. M. A. (2019). Perceived Ease of Use, Trust and Risk toward Attitude and 
Intention in Shopping for Online Fashion Products In Indonesia. Archives of Business Research, 7(4), $240-253$. https://doi.org/DOI: http://dx.doi.org/10.14738/abr.74.2019

Suleman, D., Ali, H., Nusraningrum, D., \& Ali, M. M. (2020a). Consumer Behaviour in the Marketing 4.0 Era Regarding Decisions about Where to Shop. International Journal of Innovation, Creativity and Change, 13(7), 444-456. https://www.ijicc.net/images/vol_13/Iss_7/13763_Suleman_2020_E_R.pdf

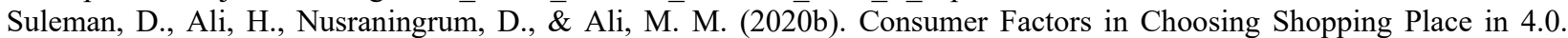 JURNAL MANAJEMEN DAN BISNIS SRIWIJAYA, 17(4), 193-198. https://doi.org/DOI: https://doi.org/10.29259/jmbs.v17i4.11529

Suleman, D., Ali, H., Nusraningrum, D., \& Ali, M. M. (2020c). Faktor konsumen dalam memilih tempat belanja di Era 4.0. At-Tijaroh, 6(1), 37-44.

Suleman, D., Ali, H., Nusraningrum, D., \& Ali, M. M. (2020d). Strategi memenangkan persaingan bisnis berbasis perilaku konsumen untuk produk fashion. Lembaga pendidikan dan pelatihan balai insan cendekia.

Suleman, D., Ali, H., Nusraningrum, D., \& Ali, M. M. A. (2019). Perceived Ease of Use, Trust and Risk toward Attitude and Intention in Shopping for Online Fashion Products In Indonesia. Archives of Business Research, 7(4), $240-253$. https://doi.org/DOI: http://dx.doi.org/10.14738/abr.74.2019

Suleman, D., Ali, H., Nusraningrum, D., \& Ali, M. M. A. (2020e). Pembeda Konsumen Dalam Memilih Tempat Belanja Offline Vs Online. Ecodemica, 4(2), 275-282.

Suleman, D., Suharyadi, D., Marwansyah, S., Rachmawati, S., Rusiyati, S., \& Sabil, S. (2020). The effect of ease of use, risks towards consumer decisions when shopping online. Dinasti International Journal of Economics, Finance \& Accounting, 1(4), 722-726. https://doi.org/DOI:10.38035/DIJEFA

Suleman, D., Suharyadi, D., Rusiyati, S., Sabil, Riftiasari, D., \& Marwansyah, S. (2020). How trust,risk toward attitude when shopping retail online. Dinasti International Journal of Education Management and Social Science, 1(4), 487-492. https://doi.org/https://doi.org/10.31933/dijms.v1i4.185

Suleman, D., Zuniarti, I., Marginingsih, R., Sabil, Nurhayaty, E., Rachmawati, S., Pramularso, E. Y., \& Sari, I. (2019). Competition between offline and online stores: when it comes to shopping for fashion products, which store will be the choice of Indonesian consumers? International Conference on Global Innovation and Trends in Economy, 1-14. https://easychair.org/publications/preprint/8drP

Suleman, D., Zuniarti, I., \& Sabil, S. (2019). Consumer Decisions toward Fashion Product Shopping in Indonesia: The effects of Attitude, Perception of Ease of Use, Usefulness, and Trust. Management Dynamics in the Knowledge Economy, 7(2), 133-146. https://doi.org/10.25019/mdke/7.2.01

Suleman, D., Zuniarti, I., Setyaningsih, E. D., Yanti, V. A., Susilowati, I. H., Sari, I., Marwansyah, S., Hadi, S. sudarmono, \& Lestiningsih, A. S. (2019). Decision Model Based on Technology Acceptance Model (Tam) for Online Shop Consumers in Indonesia. Academy of Marketing Studies Journal, 23(4), 1-14. https://www.abacademies.org/articles/decision-modelbased-on-technology-acceptance-model-tam-for-online-shop-consumers-in-indonesia-8624.html

Tingchi Liu, M., Chu, R., Wong, I. A., Angel Zúñiga, M., Meng, Y., \& Pang, C. (2012). Exploring the relationship among affective loyalty, perceived benefits, attitude, and intention to use co branded products. Asia Pacific Journal of Marketing and Logistics, 24(4), 561-582. https://doi.org/10.1108/13555851211259025

Wahyuningtyas, Y. F., \& Widiastuti, D. A. (2017). Analisis Pengaruh Persepsi Risiko, Kemudahan Dan Manfaat Terhadap Keputusan Pembelian Secara Online (Studi Kasus Pada Konsumen Barang Fashion Di Facebook). Kajian Bisnis STIE Widya Wiwaha, 23(2), 112-120. https://doi.org/10.32477/jkb.v23i2.208

Wu, W. Y., \& Ke, C. C. (2015). An online shopping behavior model integrating personality traits, perceived risk, and technology acceptance. Social Behavior and Personality, 43(1), 85-98. https://doi.org/10.2224/sbp.2015.43.1.85

Zeba, F., \& Ganguli, S. (2016). Word-of-mouth, trust, and perceived risk in online shopping: An extension of the technology acceptance model. International Journal of Information Systems in the Service Sector, 8(4), 17-32. https://doi.org/10.4018/IJISSS.2016100102

Zolait, A. H., Isa, S. M., Ali, H. M., \& Sundram, V. P. K. (2018). Men vs. Women: Study of online shopping habits and factors influencing buying decisions in Bahrain. International Journal of E-Services and Mobile Applications, 10(4), 6173. https://doi.org/10.4018/IJESMA.2018100104

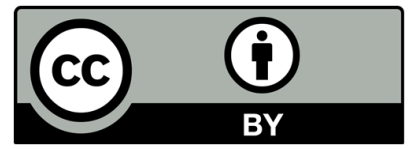

(C) 2021 by the authors; licensee Growing Science, Canada. This is an open access article distributed under the terms and conditions of the Creative Commons Attribution (CC-BY) license (http://creativecommons.org/licenses/by/4.0/). 